\title{
Systematic Review \\ The Carcinogenic Effects of Formaldehyde Occupational Exposure: A Systematic Review
}

\author{
Carmela Protano ${ }^{1} \mathbb{1}$, Giuseppe Buomprisco ${ }^{2}$, Vittoria Cammalleri ${ }^{1}$, Roberta Noemi Pocino ${ }^{1}$, Daniela Marotta ${ }^{1}$, \\ Stefano Simonazzi ${ }^{2}$, Francesca Cardoni ${ }^{2}$, Marta Petyx ${ }^{3}$, Sergio Iavicoli ${ }^{3}$ and Matteo Vitali ${ }^{1, *}$ (i)
}

1 Department of Public Health and Infectious Diseases, Sapienza University of Rome, P.le Aldo Moro 5, 00185 Rome, Italy; carmela.protano@uniroma1.it (C.P.); vittoria.cammalleri@uniroma1.it (V.C.); robertanoemi.pocino@uniroma1.it (R.N.P.); daniela.marotta@uniroma1.it (D.M.)

2 Department of Human Anatomy, Histology, Forensic Medicine and Orthopedics, Sapienza University of Rome, P.le Aldo Moro 5, 00185 Rome, Italy; giuseppe.buomprisco@uniroma1.it (G.B.); stefano.simonazzi@uniroma1.it (S.S.); francesca.cardoni@uniroma1.it (F.C.)

3 Department of Occupational and Environmental Medicine, Epidemiology and Hygiene, INAIL, Via Fontana Candida 1, 00078 Monte Porzio Catone, Rome, Italy; m.petyx@inail.it (M.P.); s.iavicoli@inail.it (S.I.)

* Correspondence: matteo.vitali@uniroma1.it

check for updates

Citation: Protano, C.; Buomprisco, G.; Cammalleri, V.; Pocino, R.N.; Marotta, D.; Simonazzi, S.; Cardoni, F.; Petyx, M.; Iavicoli, S.; Vitali, M. The Carcinogenic Effects of Formaldehyde Occupational Exposure: A Systematic Review. Cancers 2022, 14, 165. https:// doi.org/10.3390/cancers14010165

Academic Editors: Venerando Rapisarda and Caterina Ledda

Received: 12 November 2021 Accepted: 28 December 2021 Published: 29 December 2021

Publisher's Note: MDPI stays neutral with regard to jurisdictional claims in published maps and institutional affiliations.

Copyright: (C) 2021 by the authors. Licensee MDPI, Basel, Switzerland. This article is an open access article distributed under the terms and conditions of the Creative Commons Attribution (CC BY) license (https:// creativecommons.org/licenses/by/ $4.0 /)$.
Simple Summary: Formaldehyde is a chemical compound present in many working activities and indoor workplaces. Occupational exposure occurs primarily by inhaling airborne formaldehyde, but it can also be absorbed through the skin or ingested. The International Agency for Research on Cancer (IARC) classified formaldehyde as a Group 1 carcinogen for humans in 2004, based on toxicological data and epidemiological evidence obtained in workplaces, all published before that year. Over the last two decades, many new studies in this field have been published, providing updated findings. The aim of the present systematic review was to synthetize the results of epidemiological studies in occupational settings carried out in the last 20 years and to evaluate whether the IARC classification was confirmed by further studies. Our results show that the evidence of correlation between formaldehyde occupational exposure and the occurrence of cancer is limited.

\begin{abstract}
Background: Formaldehyde, classified as a carcinogen in 2004, as of today is widely used in many work activities. From its classification, further studies were performed to evaluate its carcinogenicity. The aim of the systematic review is to update the evidence on occupational exposure to formaldehyde and cancer onset. Methods: The review, in accordance with the PRISMA statement, includes articles in English reporting original results of studies conducted on workers exposed to formaldehyde, considering all types of cancer, published from 1 January 2000 to 30 July 2021 and selected from the Pubmed and Scopus databases. The studies' quality was assessed by the Newcastle-Ottawa Scale. Results: A total of 21 articles were included, conducted in different European, American, and Asian countries. The most investigated occupational areas are those characterized by a deliberate use of formaldehyde. Some studies evaluated all types of cancer, whereas others focused on specific sites such as thyroid and respiratory, lymphohematopoietic, or central nervous systems. The results showed weak associations with lung cancer, nasopharyngeal cancer, leukemia, and non-Hodgkin's lymphoma. Conclusions: The results demonstrate the need for further original studies carried out on representative samples of workers exposed to measured levels of FA. These studies should be designed to reduce the bias due to co-exposure to other carcinogens.
\end{abstract}

Keywords: formaldehyde; carcinogenicity; occupational exposure; cancer risk

\section{Introduction}

Formaldehyde (FA) is a chemical compound naturally occurring in the atmosphere, in some foods, and in the organisms of mammals as a product of oxidative metabolism and, 
thus, is considered a ubiquitous pollutant. In addition to these sources, FA can be released in the environment through combustion processes or by degradation of some hydrocarbons such as methane. Besides, due to its chemical-physical characteristics, FA is widely applied in many productive processes, such as the construction materials industry, the chemical industry (resins, paintings, etc.), the wood-processing and furniture industry, the food industry, biomedical laboratories, gross anatomy rooms, handicrafts, etc. [1]. Consequently, many types of occupational activities determine FA exposure. Driscoll et al. [2] conducted a study based on data obtained from the Australian Workplace Exposures Study about the prevalence and patterns of exposure to 38 known or suspected carcinogens, including FA, among the Australian working population. As a result, $2.5 \%$ of the workers were likely to have been exposed to FA. The main working activities that exposed them to this chemical were the processing of chipboards or plywood panels for carpentry, building maintenance, and sanding before painting. The other workers most exposed were firefighters [3-5], healthcare workers [6], and beauticians. FA has also been detected in restaurants [7,8] when grilling dishes and adding sauces, in copy shops [9,10], in gardening [11], in the agri-food sector $[12,13]$, in veterinary clinics, in embalming laboratories, in industrial launderings, etc. Besides, FA is frequently found in building environments, posing at potential risk of exposure to all indoor workers [14-19].

Exposure occurs primarily by inhaling airborne FA, but it can also be absorbed through the skin or ingested. The International Agency for Research on Cancer (IARC) in 2004 concluded that there was sufficient evidence of the carcinogenicity of FA for humans to reclassify FA from Group 2A (probably carcinogenic to humans) to Group 1 (carcinogenic to humans) [20]. In the subsequent monograph n. 100 of 2012, in summary, the IARC confirmed that there was sufficient epidemiological evidence that FA causes tumors of the nasopharynx, insufficient evidence of a causal relationship with leukemia, and limited epidemiological evidence for nasal sinus cancer [21]. EU Regulation 2015/491 also imposed the reclassification of FA from suspected carcinogen to carcinogen for humans in category 1B (i.e., it can cause cancer) on the basis of sufficient evidence both in humans [22,23] and in experimental animals [24,25]. However, all the scientific evidence that led to these classifications date back to before 2005. Besides, most of the studies on the relationship between FA and cancer were in vitro experiments demonstrated the effects on culture cells. Researchers have found many cellular damages, like DNA and RNA alterations [26,27], the onset of DNA-protein crosslinks, changes in p53 protein expression [28], and histone modifications [29]. On the other hand, epidemiological studies have not been able to confirm this association. In addition, several previous reviews investigated the relationship between occupational FA exposure and the onset of specific cancers, often obtaining conflicting conclusions [30-34]. However, no recent systematic review has looked into the relationship between occupational exposure to FA and the occurrence of cancer, except one published 15 years ago that concluded that there was no appreciable excess risk for cancers of the oral cavity and pharynx, sinus and nasal cavity, nasopharynges, and lung [35].

The aim of this systematic review is to update the scientific evidence on the relationship between occupational exposure to FA and the occurrence of all kinds of cancer evaluated by epidemiological studies performed on humans. The results of the review might help to confirm the evidence already produced by previous studies, or to highlight the need to review the current classification and/or to carry out new studies.

\section{Materials and Methods}

The presentation of this systematic review is in accordance with the latest version of the PRISMA statement [36]. We started the review process before the publication of the PRISMA Statement 2020; for this reason, the first steps of the review were conducted following the old version (PRISMA Statement 2009), which was less stringent in the "protocol and registration" item, reporting the following sentence "Indicate if a review protocol exists, if and where it can be accessed (e.g., Web address), and, if available, provide registration information including registration number)". Thus, initially we did not register the protocol 
in any database and, then, it was too late to do it because the protocol registration must be performed before the start of the review process. Zotero citation management software (RRID:SCR_013784) was used to identify any duplicates and to manage and screen the identified records.

\subsection{Literature Research}

The review includes articles published in the last 20 years, from 1 January 2000 to 31 July 2021, on the databases Pubmed and Scopus. The search strategy used a combination of controlled vocabulary and free text terms based on the following keywords: "formaldehyde", "cancer", "tumor", "neoplasm", "occupational", and "exposure". Additionally, a hand search of the reference lists of the selected articles was carried out for a wider analysis. Four independent reviewers (V.C., R.N.P., D.M. and G.B.) performed the search, reading the titles and abstracts of the articles identified by the search strategy.

During the multi-step exclusion process, any disagreement on the studies was discussed until consensus. The process was supervised by other investigators (C.P. and M.V.).

Figure S1 (Supplementary Materials) shows the flow chart summarizing the selection steps for the systematic review.

\subsection{Inclusion and Exclusion Criteria}

The review included only studies in which the participants were classified as "exposed to formaldehyde." The exposure assessment was considered acceptable if performed by direct (personal or environmental) sampling of FA, occupational history data, or job exposure matrix. Cancers were classified using the International Classification of Diseases, Tenth Revision (ICD-10).

Only studies involving humans (men and/or women) exposed to FA in occupational settings, reporting results for any kind of cancer and published in peer-reviewed journals, were selected. Searches providing no information about the exposure assessment method or with a self-assessment by the participants were excluded. Besides, we excluded reviews, editorial articles, individual contributions (i.e., conference speeches), and purely descriptive studies published in scientific conferences without any quantitative or qualitative conclusions. Finally, articles published in languages other than English were excluded.

\subsection{Data Analysis}

From each study included in the review, the following data were extracted: publication year, exposure time period, study design, working population studied, cancer type (ICD-10 classification), exposure assessment, and main conclusions.

\subsection{Quality Evaluation}

Four different reviewers (V.C., R.N.P., D.M. and G.B.) assessed the methodological quality of the selected studies with a specific rating tool, the Newcastle-Ottawa Scale (NOS), adapted for evaluating case-control, cross-sectional, and cohort studies [37]. It is divided into eight categories checking three quality aspects: selection, comparability and outcome/exposure; scores range from 0 to 9 . The quality of a study was considered to be high if the NOS score was 7 to 9 , intermediate if the NOS score was 4 to 6 , and low if it was 0 to 3 .

\section{Results}

In total, we recovered 1029 studies from all searched databases $(n=629$ from Scopus and $n=400$ from Pubmed) and, after applying filters by automation tools, 390 articles remained. Out of the remaining 390 papers, 350 were excluded after removing duplicates. Successively, one more paper was removed after reading the abstract. Then, the full texts of 39 studies were checked and evaluated considering the inclusion/exclusion criteria. A total of 14 papers were then excluded because they did not fit the inclusion criteria. Besides, eight articles were based on the same studied cohort; thus, we considered only the most 
recent, excluding those previously published. Six articles were found via citation search and four were included after checking their eligibility, whereas two were discarded due to the difficulty of extrapolating FA exposure. At the end of the process, 21 articles were included in the systematic review [38-58]. The PRISMA Flow Diagram is available as Supplementary Materials (Figure S1).

Table 1 shows the characteristics of the studies included, with reference to country, workers' gender, sample size, working context, study period, smoking adjustment, exposure assessment, cancer type, and main conclusions.

\subsection{Characteristics of the Included Studies}

The studies included were conducted on almost all continents, with six from Europe, nine from North America, four from Asia, one from South America, and one multicenter study. Most (11 studies) involved both sexes, seven involved only males, and three only females. In total, 11 case-control studies, eight cohort studies, and two case-cohort studies were considered. Industry and manufacturing were the most examined working contexts, in particular the sectors of chemical, plywood, and textile production. Therefore, the majority of the studies included (n. 11) regarded workers exposed to FA in several working contexts and workplaces. Twelve studies considered smoking a confounding factor and adjusted the results accordingly. Only three research groups performed the direct exposure assessment through personal or environmental sampling; the others assessed the exposure level indirectly by job exposure matrix or occupational history data. Five studies looked for the relationship between FA exposure and the onset of any cancer, seven evaluated the onset of upper airway cancers, four focused on lung cancer, two focused on lympho-hematopoietic cancers, one focused on thyroid cancer, and one focused on meningioma. The sample size was very variable, ranging from two cases and five controls in the smallest case-cohort study to a cohort of 1.2 million workers in the study by Siew et al. [51].

\subsection{Scoring Results}

The median NOS score of the included studies was 7, thus indicating a high average quality level. Table 2 shows the results of the scoring method applied to each study included in the review, with reference to publication year, study design, and main statistical results achieved (expressed as odds ratio, hazard ratio, relative risk, or standardized mortality ratio and with a $95 \%$ confidence interval). 
Table 1. Characteristics of the studies $(n=21)$ included in the systematic review.

\begin{tabular}{|c|c|c|c|c|c|c|c|c|}
\hline $\begin{array}{l}\text { Reference } \\
{[n .]-\text { Country }}\end{array}$ & $\begin{array}{l}\text { Workers' } \\
\text { Gender }\end{array}$ & Sample Size * & Working Context & $\begin{array}{l}\text { Study } \\
\text { Period }\end{array}$ & $\begin{array}{l}\text { Risk-Adjusted } \\
\text { for Smoking } \\
\text { Habits }\end{array}$ & $\begin{array}{l}\text { Exposure } \\
\text { Assessment }\end{array}$ & $\begin{array}{l}\text { Cancer Type } \\
\text { (ICD-10) }\end{array}$ & Main Conclusions \\
\hline [38]—Malaysia & Both & $\begin{array}{l}49 \text { cases, } \\
49 \text { controls }\end{array}$ & $\begin{array}{l}\text { Chemical, plywood, and } \\
\text { textile industries }\end{array}$ & 1990-1992 & Yes & Air sampling ** & $\begin{array}{l}\text { Nasopharyngeal } \\
\text { cancer (C11.9) }\end{array}$ & $\begin{array}{c}\text { No association was found between nasopharyngeal } \\
\text { carcinoma and FA. }\end{array}$ \\
\hline [39]—USA & Both & $\begin{array}{l}79 \text { cases, } \\
79 \text { controls }\end{array}$ & Various & 1987-1993 & Yes & $\begin{array}{l}\text { Occupational } \\
\text { history data }\end{array}$ & $\begin{array}{l}\text { Nasopharyngeal } \\
\text { cancer (C11.9) }\end{array}$ & $\begin{array}{l}\text { Results from this study support the hypothesis that } \\
\text { occupational exposure to FA increases risk of NPC. } \\
\text { The association between risk of NPC and potential } \\
\text { exposure to FA was stronger among cigarette smokers. }\end{array}$ \\
\hline [40]-France & Men & $\begin{array}{l}\text { Laryngeal: } 102 \text { cases, } \\
85 \text { controls } \\
\text { Hypopharyngeal: } \\
83 \text { cases, } \\
85 \text { controls }\end{array}$ & Various & 1987-1991 & Yes & $\begin{array}{l}\text { Job exposure } \\
\text { matrix }\end{array}$ & $\begin{array}{l}\text { Laryngeal and } \\
\text { hypopharyngeal } \\
\text { cancer (C10.9) }\end{array}$ & $\begin{array}{c}\text { Exposure to FA was associated with an increased risk } \\
\text { of hypopharyngeal cancer. No association with } \\
\text { laryngeal cancer was found. }\end{array}$ \\
\hline [41]-Taiwan & Both & $\begin{array}{l}74 \text { cases, } \\
41 \text { controls }\end{array}$ & Various & 1991-1994 & Yes & $\begin{array}{l}\text { Occupational } \\
\text { history data }\end{array}$ & $\begin{array}{l}\text { Nasopharyngeal } \\
\text { cancer (C11.9) }\end{array}$ & $\begin{array}{l}\text { There was some evidence of increasing risk of NPC } \\
\text { with increasing years of exposure to FA, but the } \\
\text { observed trend did not achieve statistical significance. }\end{array}$ \\
\hline $\begin{array}{l}\text { [42]-Northern } \\
\text { Europe }\end{array}$ & Men & 108 cases, 398 controls & $\begin{array}{l}\text { Vitreous fiber-producing } \\
\text { plants }\end{array}$ & 1971-1996 & Yes & $\begin{array}{l}\text { Occupational } \\
\text { history data } \\
\text { Personal }\end{array}$ & $\begin{array}{l}\text { Lung cancer } \\
\text { (C34) }\end{array}$ & $\begin{array}{l}\text { This study provides no evidence of a carcinogenic } \\
\text { effect on the lungs from FA exposure. } \\
\text { Results support a possible relation between FA }\end{array}$ \\
\hline [43]—USA & Both & 11,039 & Various & 1955-1998 & Not & $\begin{array}{l}\text { sampling among } \\
\text { workers }(1981 \\
\text { and 1984) }\end{array}$ & $\begin{array}{l}\text { All cancers } \\
\text { (C00-C97) }\end{array}$ & $\begin{array}{l}\text { exposure and myeloid leukemia mortality. } \\
\text { Non-significant excesses in mortality were observed } \\
\text { among FA-exposed workers for several other cancers. }\end{array}$ \\
\hline [44]_Uruguay & Men & $\begin{array}{l}32 \text { cases, } \\
65 \text { controls }\end{array}$ & $\begin{array}{l}\text { Agricultural workers, } \\
\text { histology technicians, } \\
\text { medical personnel, } \\
\text { and foundry workers }\end{array}$ & 1994-2000 & Yes & $\begin{array}{l}\text { Occupational } \\
\text { history data }\end{array}$ & $\begin{array}{l}\text { Lung cancer } \\
\text { (C34) }\end{array}$ & $\begin{array}{l}\text { Constant exposure to FA was significantly associated } \\
\text { with an increased OR of adenocarcinoma of the lung. }\end{array}$ \\
\hline $\begin{array}{l}\text { [45]-Central } \\
\text { and Eastern } \\
\text { Europe }\end{array}$ & Men & 18 cases, 30 controls & Various & 1999-2002 & Yes & $\begin{array}{l}\text { Occupational } \\
\text { history data }\end{array}$ & $\begin{array}{l}\text { Laryngeal cancer } \\
\text { (C32) } \\
\text { Hypopharyngeal } \\
\text { cancer (C12, } \\
\text { C13) }\end{array}$ & $\begin{array}{l}\text { No overall association } \\
\text { was found between FA and laryngeal cancer. }\end{array}$ \\
\hline [46]—China & Women & $\begin{array}{l}2 \text { cases, } \\
11 \text { subcohort non-cases }\end{array}$ & Textile industries & 1989-1998 & Not & $\begin{array}{l}\text { Historical } \\
\text { measurements } \\
\text { data }\end{array}$ & $\begin{array}{l}\text { Thyroid cancer } \\
\text { (C73) }\end{array}$ & $\begin{array}{l}\text { Associations were observed between thyroid cancer } \\
\text { and employment in jobs with } 10 \text { or more years of FA } \\
\text { exposure. }\end{array}$ \\
\hline [47]-USA & Both & 7345 & Plastic-producing plants & 1979-2003 & Yes & $\begin{array}{l}\text { Occupational } \\
\text { history data }\end{array}$ & $\begin{array}{l}\text { Nasopharyngeal } \\
\text { cancer (C11.9) }\end{array}$ & $\begin{array}{l}\text { Overall, the pattern of findings suggests that the large, } \\
\text { persistent nasopharyngeal and other PC excesses } \\
\text { observed were not associated with FA exposure. } \\
\text { Interaction models suggest that NPC and AOPC risks } \\
\text { were not elevated in subjects exposed only to FA. }\end{array}$ \\
\hline
\end{tabular}


Table 1. Cont.

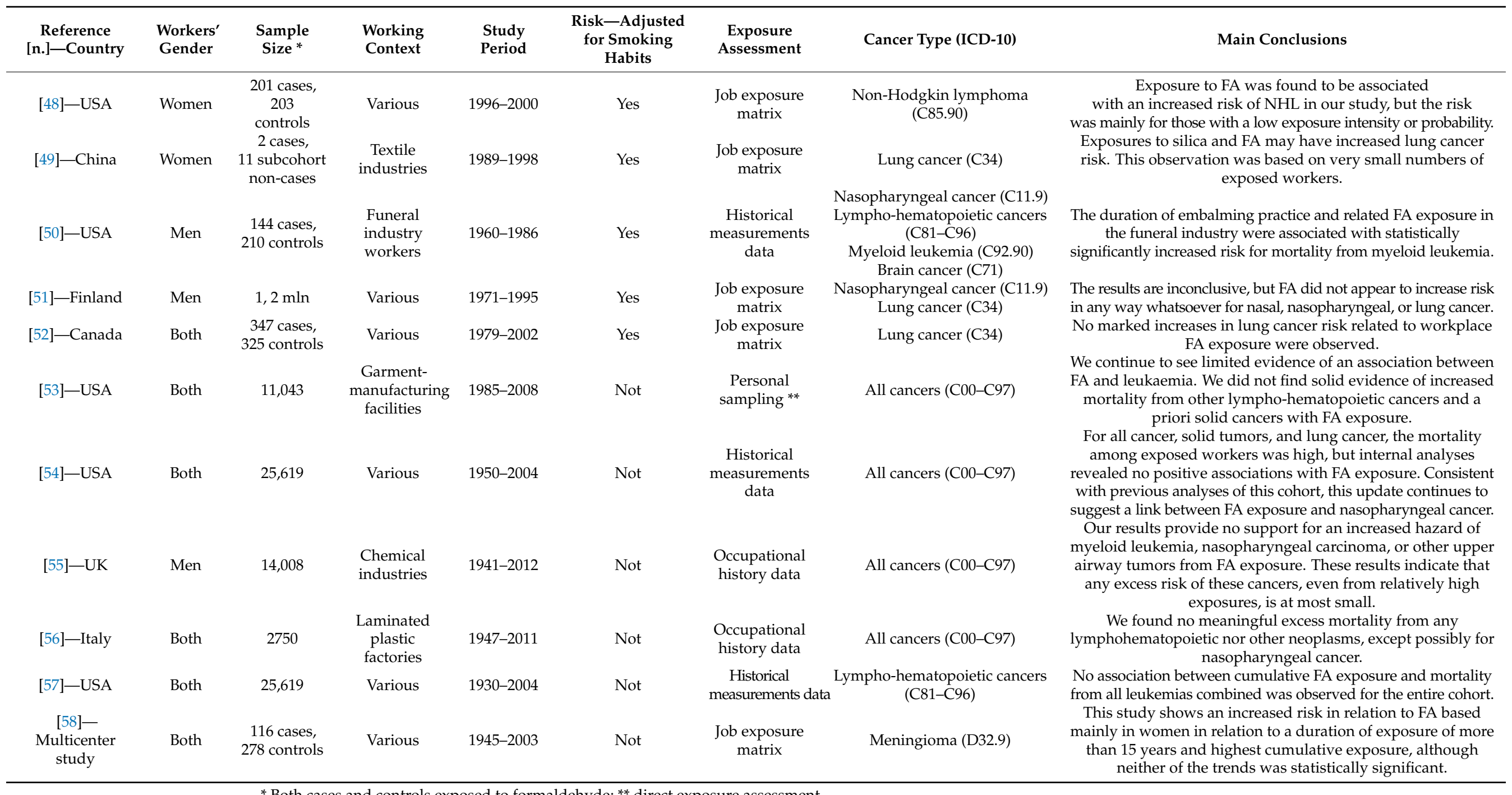


Table 2. Scoring results of the included studies in relation to study design, year of publication, and statistical results achieved.

\begin{tabular}{|c|c|c|c|}
\hline Reference [n.]-Year & Study Design & Statistical Results & NOS Score \\
\hline$[38]-2000$ & Case-control & Nasopharyngeal cancer: OR: 0.88 (CI: 0.70-1.12) & 7 \\
\hline$[39]-2000$ & Case-control & Nasopharyngeal cancer: OR: 1.3 (CI: 0.80-2.1) & 7 \\
\hline$[40]-2000$ & Case-control & $\begin{array}{l}\text { Hypopharyngeal cancer: OR: } 1.35 \text { (CI: 0.86-2.14) } \\
\text { Oropharyngeal cancer: OR: } 1.14 \text { (CI: } 0.76-1.70)\end{array}$ & 6 \\
\hline$[41]-2001$ & Case-control & Nasopharyngeal cancer: OR: 1.4 (CI: 0.93-2.2)* & 6 \\
\hline [42]-2002 & Case-control & Lung cancer: OR: 1.33 (CI: 0.76-2.34) & 7 \\
\hline$[43]-2004$ & Cohort & $\begin{array}{l}\text { All cancers: SMR: } 0.89 \text { (CI: } 0.82-0.97) \\
\text { Myeloid leukemia: SMR: } 1.44 \text { (CI: } 0.80-2.37)\end{array}$ & 7 \\
\hline$[44]-2005$ & Case-control & Lung cancer: OR: 1.7 (CI: $1.1-2.8)$ & 6 \\
\hline$[45]-2006$ & Case-control & Laryngeal cancer: OR 1.68 (CI: $0.85-3.31)$ * & 6 \\
\hline$[46]-2006$ & Case-cohort & Thyroid cancer: HR: 8.33 (CI: 1.16-60) & 7 \\
\hline$[47]-2007$ & Cohort & $\begin{array}{l}\text { Nasopharyngeal cancer: SMR: } 4.43 \text { (CI: 1.78-9.13) } \\
\text { Other pharynx cancers: SMR: } 1.71 \text { (CI: } 1.01-2.72)\end{array}$ & 7 \\
\hline$[48]-2008$ & Case-control & $\begin{array}{l}\text { Non-Hodgkin lymphoma: OR: } 1.3 \text { (CI: } 1.0-1.7) \\
\text { Nasopharyngeal cancer: OR: } 0.1 \text { (CI: } 0.01-1.2)\end{array}$ & 7 \\
\hline$[49]-2009$ & Case-cohort & $\begin{array}{c}\text { Lympho-hematopoietic cancers: OR: } 0.9 \text { (CI: 0.4-2.1) * } \\
\text { Myeloid leukemia: OR: } 3.9 \text { (CI: } 1.2-12.5) \\
\text { Brain cancer: OR: } 1.9 \text { (CI: } 0.7-5.3)^{*}\end{array}$ & \\
\hline$[50]-2011$ & Case-cohort & Lung cancer: HR: $2.10(0.40-11.00)$ & 8 \\
\hline$[51]-2012$ & Cohort & $\begin{array}{l}\text { Nasopharyngeal cancer: RR: } 0.87 \text { (CI: } 0.34-2.20) \\
\text { Lung cancer: RR: } 1.18 \text { (CI: } 1.12-1.25)\end{array}$ & 8 \\
\hline [52]-2013 & Case-control & Lung cancer: OR: 1.06 (CI: 0.89-1.27) & 7 \\
\hline [53]-2013 & Cohort & All cancers: SMR: 0.96 (CI: 0.90-1.02) & 7 \\
\hline [54]-2013 & Cohort & All cancers: SMR: 1.08 (CI: 1.05-1.12) & 7 \\
\hline [55]-2014 & Cohort & All cancers: SMR: 1.10 (CI: 1.06-1.15) & 7 \\
\hline$[56]-2014$ & Cohort & All cancers: SMR: 79.8 (CI: 67.5-93.6) & 6 \\
\hline [57]-2016 & Cohort & Lymphohematopoietic cancers: SMR: 2.07 (CI: 1.22-3.49) & 8 \\
\hline [58]-2018 & Case-control & Meningioma: OR: 1.02 (CI: $0.80-1.29)$ & 7 \\
\hline
\end{tabular}

*: Not statistically significant; CI: 95\% confidence interval; OR: odds ratio; HR: hazard ratio; RR: relative risk; SMR: standardized mortality ratio.

\section{Discussion}

We performed a systematic review on the association between FA occupational exposure and the occurrence of cancer in potentially exposed workers.

Previous studies about FA and cancer risk suggested a modest excess of risk for nasopharyngeal cancer [59], but the studied cohort of workers was co-exposed to several other chemicals, resulting in additive and/or synergic effects or misleading results. Despite this, the findings were included by the IARC in its evaluation, even if subsequent analysis revealed no statistical significance of these results and highlighted the inappropriateness of the adopted exposure assessment approach [60].

Among the studies included in our review, we found a direct assessment of the exposure levels of FA only in three papers. In the other cases, the exposure assessment was indirectly extrapolated considering the length of exposure and the type of activities performed (e.g., job exposure matrix). Most of the studies included in this review dealt with occupational settings, characterized by a deliberate use of FA as a component of the production cycle. Those were mainly represented by chemical industries dedicated to the production of plastics, fiberglass, paints, etc.; it is reasonable to imagine that in such contexts the levels of exposure to FA were particularly high. Three studies were carried out in textile-/garment-producing plants, where FA is used to give resistance to the folds of clothing fabrics and for the processing of leathers. Another sector where this substance is widely used is that of woodworking and furniture making. In fact, FA, together with resins, gives strength and resistance to chipboard panels. FA is also widely used in the medical field: in the operating room it was used to disinfect instruments because of its high antibacterial power, and even today, it is used to avoid the deterioration of human tissues 
that must undergo histopathological analyses. Despite that, very few studies concerned the health sector, or the agri-food industry, where FA is used as a preservative. That is quite surprising, considering that there is much research about the occupational exposure to FA in pathological anatomy settings and sector rooms [61-63] that stress the needing for adequate preventive measures for workers [64].

Although the genotoxicity and immunotoxicity of FA is well known and has been demonstrated by several studies regarding its influence on DNA and pro-oxidative effects on cells [28,65-72], the evidence from human studies and diagnosed cancers is much less consistent [73]. Most of the studies included in this review focus on upper-airway neoplasms (ICD-10 codes: C10-C14 and C30-C33), as mentioned previously. In fact, the main way of entry of this substance into the body is by inhalation. Five studies explored the relationship between FA occupational exposure and the onset of lung cancer (ICD-10 code: C34). Their findings contrasted with each other: some did not provide evidence of a carcinogenic effect on the lungs [42,51,52], whereas others found a correlation [44,49]. These last studies, however, were performed on a very small sample and present several limitations (e.g., self-reported data on exposure levels). A recent meta-analysis by Kwak et al. [31] concluded no significant increase in the risk of lung cancer, even considering only groups of highly exposed workers. The small study sample of the study by Checkoway et al. about lung cancer was also checked for thyroid cancer, with some relationships found but with the same, considerable, limitations [46]. In 2012, the IARC affirmed that there was strong but insufficient evidence of a causal relationship with leukemia. Two studies included in our review regarded the relationship between FA exposure and lympho-hematopoietic cancers (ICD-10 codes: C81-C96), but no association was observed for all leukemias [56], except for a small and weak association with non-Hodgkin lymphoma [48] and myeloid leukemia [50]. This is consistent with the results of other previous studies [30,33]. Five of the included publications evaluated the effects of FA occupational exposure on the onset of any kind of cancer. These were large cohort studies, carried out in Europe and the USA in industrial contexts, and almost all concluded no positive association with FA exposure and the mortality from any cancer, and very limited evidence with NPC and leukemia [43,53-56]. The most recent research included, published in 2018, was a multicenter study about FA and meningioma. Meningiomas are tumors that develop from the meninges, tissues that surround the outside of the brain and account for about $30 \%$ of brain tumors. Although benign, they are dangerous because dysphagia, dysarthria, ocular motility disorders, and facial numbness can occur. Intracranial hypertension, focal seizures, lack of strength, and balance and gait disturbances may also sometimes occur. The study concluded that FA did not provoke excess risks of meningioma [58].

The present systematic review has some limitations. First of all, we considered only papers published in the last 20 years, but this choice was driven by the aim of the present systematic review. Secondly, we considered only articles published in the English language, excluding a priori potentially useful results published in other languages. Finally, we did not perform a formal meta-analysis because the studies included in the review were different in terms of exposure assessment methodologies, kind of cancers considered, and study design. For this reason, statistical heterogeneity and publication bias were not evaluated. Our choice is well supported by a very recent official statement by Cochrane on the opportunity for performing a meta-analysis when data are heterogeneous: "Metaanalysis should only be considered when a group of studies is sufficiently homogeneous in terms of participants, interventions and outcomes to provide a meaningful summary. It is often appropriate to take a broader perspective in a meta-analysis than in a single clinical trial. A common analogy is that systematic reviews bring together apples and oranges, and that combining these can yield a meaningless result" [74].

\section{Conclusions}

FA has been classified by the IARC as a Group I carcinogen since 2004; this classification was based on evidence obtained in preceding years. Reviewing the scientific 
literature published in the last 20 years, we found at least 21 additional epidemiological studies on the association between occupational exposure to FA and cancer onset. This finding indicates the need for an update of the FA classification based on the new evidence. On the other hand, the results of the examined papers do not completely confirm the IARC classification of FA and give contrasting results. Thus, it is essential to perform further original studies carried out on representative samples of workers exposed to measured levels of FA. These studies should be designed to reduce bias as much as possible due to co-exposure to other carcinogens.

Supplementary Materials: The following are available online at https:/ /www.mdpi.com/article/10 .3390/cancers14010165/s1, Figure S1: PRISMA flow diagram.

Author Contributions: Conceptualization, C.P. and M.V.; methodology, C.P.; formal analysis, G.B., V.C., R.N.P. and D.M.; investigation, G.B., V.C., R.N.P. and D.M.; data curation, S.I., M.P., S.S. and F.C.; writing—original draft preparation, G.B.; writing—review and editing, S.I., M.P., C.P. and M.V.; supervision, C.P., S.S., F.C. and M.V.; project administration, F.C. and M.V. All authors have read and agreed to the published version of the manuscript.

Funding: This research was funded by INAIL, BRiC-2018, project number B86C19000070001.

Data Availability Statement: Data are provided as tables and figures directly within the manuscript, and raw data are available via e-mail upon request to the corresponding author.

Conflicts of Interest: The authors declare no conflict of interest. The funders had no role in the design of the study; in the collection, analyses, or interpretation of data; in the writing of the manuscript, or in the decision to publish the results.

\section{References}

1. Cammalleri, V.; Pocino, R.N.; Marotta, D.; Protano, C.; Sinibaldi, F.; Simonazzi, S.; Petyx, M.; Iavicoli, S.; Vitali, M. Occupational scenarios and exposure assessment to formaldehyde: A systematic review. Indoor Air, 2021, in press. [CrossRef]

2. Driscoll, T.R.; Carey, R.N.; Peters, S.; Glass, D.C.; Benke, G.; Reid, A.; Fritschi, L. The Australian Work Exposures Study: Prevalence of Occupational Exposure to Formaldehyde. Ann. Occup. Hyg. 2016, 60, 132-138. [CrossRef] [PubMed]

3. Reisen, F.; Brown, S.K. Australian firefighters' exposure to air toxics during bushfire burns of autumn 2005 and 2006. Environ. Int. 2009, 35, 342-352. [CrossRef] [PubMed]

4. Laitinen, J.; Makela, M.; Mikkola, J.; Huttu, I. Fire fighting trainers' exposure to carcinogenic agents in smoke diving simulators. Toxicol. Lett. 2010, 192, 61-65. [CrossRef] [PubMed]

5. Jankovic, J.; Jones, W.; Burkhart, J.; Noonan, G. Environmental study of firefighters. Ann. Occup. Hyg. 1991, 35, 581-602. [CrossRef] [PubMed]

6. Vecchio, D.; Sasco, A.J.; Cann, C.I. Occupational risk in health care and research. Am. J. Ind. Med. 2003, 43, 369-397. [CrossRef] [PubMed]

7. Que, D.E.; Chao, H.R.; Hsu, Y.C.; Cui, K.; Chen, S.; Tayo, L.L.; Arcega, R.D.; Tsai, Y.I.; Lu, I.C.; Wang, L.C.; et al. Emission of carbonyl compounds from cooking oil fumes in the night market areas. Aerosol. Air Qual. Res. 2019, 19, 1566-1578. [CrossRef]

8. Jung, J.H.; Youn, S.U.; Kwon, E.; Im, S.; Akiyama, Y.; Arashidani, K.; Yang, W. Emission rates of air pollutants from portable gas ranges and nitrogen dioxide exposure assessment in restaurants. J. UOEH 2009, 31, 13-22. [CrossRef]

9. Su, M.; Sun, R.; Zhang, X.; Wang, S.; Zhang, P.; Yuan, Z.; Liu, C.; Wang, Q. Assessment of the inhalation risks associated with working in printing rooms: A study on the staff of eight printing rooms in Beijing, China. Environ. Sci. Pollut. Res. Int. 2018, 25, 17137-17143. [CrossRef]

10. Vicente, E.D.; Ribeiro, J.P.; Custódio, D.; Alves, C.A. Assessment of the indoor air quality in copy centers at Aveiro, Portugal. Air Qual. Atmos. Health 2017, 10, 117-127. [CrossRef]

11. Baldauf, R.; Fortune, C.; Weinstein, J.; Wheeler, M.; Blanchard, F. Air contaminant exposures during the operation of lawn and garden equipment. J. Expo. Sci. Environ. Epidemiol. 2006, 16, 362-370. [CrossRef] [PubMed]

12. Voorhees, J.M.; Barnes, M.E. Airborne Formaldehyde Levels during Simulated Formalin Egg Treatments in Vertical-Flow Tray Incubators at a Production Fish Hatchery. J. Agric. Saf. Health 2016, 22, 199-207. [CrossRef] [PubMed]

13. Doane, M.; Sarenbo, S. Exposure of farm laborers and dairy cattle to formaldehyde from footbath use at a dairy farm in New York State. Sci. Total Environ. 2014, 487, 65-71. [CrossRef] [PubMed]

14. Kim, W.J.; Terada, N.; Nomura, T.; Takahashi, R.; Lee, S.D.; Park, J.H.; Konno, A. Effect of formaldehyde on the expression of adhesion molecules in nasal microvascular endothelial cells: The role of formaldehyde in the pathogenesis of sick building syndrome. Clin. Exp. Allergy 2002, 32, 287-295. [CrossRef] [PubMed] 
15. Ho, S.S.H.; Cheng, Y.; Bai, Y.; Ho, K.F.; Dai, W.T.; Cao, J.J.; Lee, S.C.; Huang, Y.; Ip, H.S.S.; Deng, W.J.; et al. Risk assessment of indoor formaldehyde and other carbonyls in campus environments in northwestern China. Aerosol. Air Qual. Res. 2016, 16, 1967-1980. [CrossRef]

16. Pośniak, M.; Makhniashvili, I.; Koziel, E. Volatile organic compounds in the indoor air of Warsaw office buildings. Indoor Built Environ. 2005, 14, 269-275. [CrossRef]

17. Salonen, H.J.; Pasanen, A.L.; Lappalainen, S.K.; Riuttala, H.M.; Tuomi, T.M.; Pasanen, P.O.; Back, B.C.; Reijula, K.E. Airborne concentrations of volatile organic compounds, formaldehyde and ammonia in Finnish office buildings with suspected indoor air problems. J. Occup. Environ. Hyg. 2009, 6, 200-209. [CrossRef] [PubMed]

18. Hui, P.S.; Mui, K.W.; Wong, L.T. Influence of indoor air quality (IAQ) objectives on air-conditioned offices in Hong Kong. Environ. Monit. Assess. 2008, 144, 315-322. [CrossRef]

19. Kaden, D.A.; Mandin, C.; Nielsen, G.D.; Wolkoff, P. Formaldehyde. In WHO Guidelines for Indoor Air Quality: Selected Pollutants; World Health Organization: Geneva, Switzerland, 2010; Available online: https:/ / www.ncbi.nlm.nih.gov/books /NBK138711 (accessed on 10 September 2021).

20. International Agency for Research on Cancer (IARC). IARC Monographs on the Evaluation of Carcinogenic Risks to Humans: Formaldehyde, 2-Butoxyethanol and 1-Tert-Butoxypropan-2-ol. 88; International Agency for Research on Cancer: Lyon, France, 2006.

21. International Agency for Research on Cancer (IARC). IARC Monographs on the Evaluation of Carcinogenic Risks to Humans, Chemical Agents and Related Occupations, Vol 100 F, A Review of Human Carcinogen; WHO, International Agency for Research on Cancer: Lyon, France, 2012.

22. Cogliano, V.J.; Grosse, Y.; Baan, R.A.; Straif, K.; Secretan, M.B.; El Ghissassi, F. Working Group for Volume 88. Meeting report: Summary of IARC monographs on formaldehyde, 2-butoxyethanol, and 1-tert-butoxy-2-propanol. Environ. Health Perspect. 2005, 113, 1205-1208. [CrossRef]

23. Blair, A.; Saracci, R.; Stewart, P.A.; Hayes, R.B.; Shy, C. Epidemiologic evidence on the relationship between formaldehyde exposure and cancer. Scand. J. Work Environ. Health 1990, 16, 381-393. [CrossRef]

24. Kerns, W.D.; Pavkov, K.L.; Donofrio, D.J.; Gralla, E.J.; Swenberg, J.A. Carcinogenicity of formaldehyde in rats and mice after long-term inhalation exposure. Cancer Res. 1983, 43, 4382-4392.

25. Swenberg, J.A.; Kerns, W.D.; Mitchell, R.I.; Gralla, E.J.; Pavkov, K.L. Induction of squamous cell carcinomas of the rat nasal cavity by inhalation exposure to formaldehyde vapor. Cancer Res. 1980, 40, 3398-3402.

26. Ye, X.; Yan, W.; Xie, H.; Zhao, M.; Ying, C. Cytogenetic analysis of nasal mucosa cells and lymphocytes from high-level long-term formaldehyde exposed workers and low-level short-term exposed waiters. Mutat. Res. 2005, 588, 22-27. [CrossRef] [PubMed]

27. Gonzalez-Rivera, J.C.; Sherman, M.W.; Wang, D.S.; Chuvalo-Abraham, J.C.L.; Hildebrandt Ruiz, L.; Contreras, L.M. RNA oxidation in chromatin modification and DNA-damage response following exposure to formaldehyde. Sci. Rep. 2020, 10. [CrossRef]

28. Shaham, J.; Bomstein, Y.; Gurvich, R.; Rashkovsky, M.; Kaufman, Z. DNA-protein crosslinks and p53 protein expression in relation to occupational exposure to formaldehyde. Occup. Environ. Med. 2003, 60, 403-409. [CrossRef] [PubMed]

29. Lu, K.; Boysen, G.; Gao, L.; Collins, L.B.; Swenberg, J.A. Formaldehyde-induced histone modifications in vitro. Chem. Res. Toxicol. 2008, 21, 1586-1593. [CrossRef]

30. Catalani, S.; Donato, F.; Madeo, E.; Apostoli, P.; De Palma, G.; Pira, E.; Mundt, K.A.; Boffetta, P. Occupational exposure to formaldehyde and risk of non-hodgkin lymphoma: A meta-analysis. BMC Cancer 2019, 19, 1245. [CrossRef] [PubMed]

31. Kwak, K.; Paek, D.; Park, J.T. Occupational exposure to formaldehyde and risk of lung cancer: A systematic review and meta-analysis. Am. J. Ind. Med. 2020, 63, 312-327. [CrossRef]

32. Collins, J.J.; Esmen, N.A.; Hall, T.A. A review and meta-analysis of formaldehyde exposure and pancreatic cancer. Am. J. Ind Med. 2001, 39, 336-345. [CrossRef]

33. Checkoway, H.; Boffetta, P.; Mundt, D.J.; Mundt, K.A. Critical review and synthesis of the epidemiologic evidence on formaldehyde exposure and risk of leukemia and other lymphohematopoietic malignancies. Cancer Causes Control 2012, 23, 1747-1766. [CrossRef]

34. Kang, D.S.; Kim, H.S.; Jung, J.H.; Lee, C.M.; Ahn, Y.S.; Seo, Y.R. Formaldehyde exposure and leukemia risk: A comprehensive review and network-based toxicogenomic approach. Genes Environ. 2021, 43, 13. [CrossRef]

35. Bosetti, C.; McLaughlin, J.K.; Tarone, R.E.; Pira, E.; La Vecchia, C. Formaldehyde and cancer risk: A quantitative review of cohort studies through 2006. Ann. Oncol. 2008, 19, 29-43. [CrossRef] [PubMed]

36. Page, M.J.; McKenzie, J.E.; Bossuyt, P.M.; Boutron, I.; Hoffmann, T.C.; Mulrow, C.D.; Shamseer, L.; Tetzlaff, J.M.; Akl, E.A.; Brennan, S.E.; et al. The PRISMA 2020 statement: An updated guideline for reporting systematic reviews. J. Clin. Epidemiol. 2021, 134, 178-189. [CrossRef] [PubMed]

37. Wells, G.A.; Shea, B.; O'Connell, D.; Peterson, J.; Welch, V.; Losos, M.; Tugwell, P. The Newcastle-Ottawa Scale (NOS) for Assessing the Quality of Nonrandomised Studies in Meta-Analyses; Ottawa Health Research Institute: Ottawa, ON, Canada, 2014.

38. Armstrong, R.W.; Imrey, P.B.; Lye, M.S.; Armstrong, M.J.; Yu, M.C.; Sani, S. Nasopharyngeal carcinoma in Malaysian Chinese: Occupational exposures to particles, formaldehyde and heat. Int. J. Epidemiol. 2000, 29, 991-998. [CrossRef] [PubMed]

39. Vaughan, T.L.; Stewart, P.A.; Teschke, K.; Lynch, C.F.; Swanson, G.M.; Lyon, J.L.; Berwick, M. Occupational exposure to formaldehyde and wood dust and nasopharyngeal carcinoma. Occup. Environ. Med. 2000, 57, 376-384. [CrossRef] 
40. Laforest, L.; Luce, D.; Goldberg, P.; Bégin, D.; Gérin, M.; Demers, P.A.; Brugère, J.; Leclerc, A. Laryngeal and hypopharyngeal cancers and occupational exposure to formaldehyde and various dusts: A case-control study in France. Occup. Environ. Med. 2000, 57, 767-773. [CrossRef] [PubMed]

41. Hildesheim, A.; Dosemeci, M.; Chan, C.C.; Chen, C.J.; Cheng, Y.J.; Hsu, M.M.; Chen, I.H.; Mittl, B.F.; Sun, B.; Levine, P.H.; et al. Occupational exposure to wood, formaldehyde, and solvents and risk of nasopharyngeal carcinoma. Cancer Epidemiol. Biomark. Prev. 2001, 10, 1145-1153.

42. Kjaerheim, K.; Boffetta, P.; Hansen, J.; Cherrie, J.; Chang-Claude, J.; Eilber, U.; Ferro, G.; Guldner, K.; Olsen, J.H.; Plato, N.; et al. Lung cancer among rock and slag wool production workers. Epidemiology 2002, 13, 445-453. [CrossRef]

43. Pinkerton, L.E.; Hein, M.J.; Stayner, L.T. Mortality among a cohort of garment workers exposed to formaldehyde: An update. Occup. Environ. Med. 2004, 61, 193-200. [CrossRef]

44. De Stefani, E.D.; Boffetta, P.; Brennan, P.; Deneo-Pellegrini, H.; Ronco, A.; Gutiérrez, L.P. Occupational Exposures and Risk of Adenocarcinoma of the Lung in Uruguay. Cancer Causes Control 2005, 16, 851-856. [CrossRef]

45. Shangina, O.; Brennan, P.; Szeszenia-Dabrowska, N.; Mates, D.; Fabiánová, E.; Fletcher, T.; t'Mannetje, A.; Boffetta, P.; Zaridze, D. Occupational exposure and laryngeal and hypopharyngeal cancer risk in central and eastern Europe. Am. J. Epidemiol. 2006, 164, 367-375. [CrossRef]

46. Wong, E.Y.; Ray, R.; Gao, D.L.; Wernli, K.J.; Li, W.; Fitzgibbons, E.D.; Feng, Z.; Thomas, D.B.; Checkoway, H. Reproductive history, occupational exposures, and thyroid cancer risk among women textile workers in Shanghai, China. Int. Arch. Occup. Environ. Health 2006, 79, 251-258. [CrossRef]

47. Marsh, G.M.; Youk, A.O.; Buchanich, J.M.; Erdal, S.; Esmen, N.A. Work in the metal industry and nasopharyngeal cancer mortality among formaldehyde-exposed workers. Regul. Toxicol. Pharmacol. 2007, 48, 308-319. [CrossRef] [PubMed]

48. Wang, R.; Zhang, Y.; Lan, Q.; Holford, T.R.; Leaderer, B.; Zahm, S.H.; Boyle, P.; Dosemeci, M.; Rothman, N.; Zhu, Y.; et al. Occupational exposure to solvents and risk of non-Hodgkin lymphoma in Connecticut women. Am. J. Epidemiol. 2009, 169, 176-185. [CrossRef] [PubMed]

49. Checkoway, H.; Ray, R.M.; Lundin, J.I.; Astrakianakis, G.; Seixas, N.S.; Camp, J.E.; Wernli, K.J.; Fitzgibbons, E.D.; Li, W.; Feng, Z.; et al. Lung cancer and occupational exposures other than cotton dust and endotoxin among women textile workers in Shanghai, China. Occup. Environ. Med. 2011, 68, 425-429. [CrossRef] [PubMed]

50. Hauptmann, M.; Stewart, P.A.; Lubin, J.H.; Beane Freeman, L.E.; Hornung, R.W.; Herrick, R.F.; Hoover, R.N.; Fraumeni, J.F., Jr.; Blair, A.; Hayes, R.B. Mortality from lymphohematopoietic malignancies and brain cancer among embalmers exposed to formaldehyde. J. Natl. Cancer Inst. 2009, 101, 1696-1708. [CrossRef] [PubMed]

51. Siew, S.S.; Kauppinen, T.; Kyyrönen, P.; Heikkilä, P.; Pukkala, E. Occupational exposure to wood dust and formaldehyde and risk of nasal, nasopharyngeal, and lung cancer among Finnish men. Cancer Manag. Res. 2012, 4, 223-232. [CrossRef]

52. Mahboubi, A.; Koushik, A.; Siemiatycki, J.; Lavoué, J.; Rousseau, M.C. Assessment of the effect of occupational exposure to formaldehyde on the risk of lung cancer in two Canadian population-based case-control studies. Scand. J. Work Environ. Health 2013, 39, 401-410. [CrossRef]

53. Meyers, A.R.; Pinkerton, L.E.; Hein, M.J. Cohort mortality study of garment industry workers exposed to formaldehyde: Update and internal comparisons. Am. J. Ind. Med. 2013, 56, 1027-1039. [CrossRef]

54. Beane Freeman, L.E.; Blair, A.; Lubin, J.H.; Stewart, P.A.; Hayes, R.B.; Hoover, R.N.; Hauptmann, M. Mortality from solid tumors among workers in formaldehyde industries: An update of the NCI cohort. Am. J. Ind. Med. 2013, 56, 1015-1026. [CrossRef]

55. Coggon, D.; Ntani, G.; Harris, E.C.; Palmer, K.T. Upper airway cancer, myeloid leukemia, and other cancers in a cohort of British chemical workers exposed to formaldehyde. Am. J. Epidemiol. 2014, 179, 1301-1311. [CrossRef]

56. Pira, E.; Romano, C.; Verga, F.; La Vecchia, C. Mortality from lymphohematopoietic neoplasms and other causes in a cohort of laminated plastic workers exposed to formaldehyde. Cancer Causes Control 2014, 25, 1343-1349. [CrossRef] [PubMed]

57. Checkoway, H.; Dell, L.D.; Boffetta, P.; Gallagher, A.E.; Crawford, L.; Lees, P.S.; Mundt, K.A. Formaldehyde Exposure and Mortality Risks from Acute Myeloid Leukemia and Other Lymphohematopoietic Malignancies in the US National Cancer Institute Cohort Study of Workers in Formaldehyde Industries. J. Occup. Environ. Med. 2015, 57, 785-794. [CrossRef] [PubMed]

58. McElvenny, D.M.; van Tongeren, M.; Turner, M.C.; Benke, G.; Figuerola, J.; Fleming, S.; Hours, M.; Kincl, L.; Krewski, D.; McLean, D.; et al. The INTEROCC case-control study: Risk of meningioma and occupational exposure to selected combustion products, dusts and other chemical agents. Occup. Environ. Med. 2018, 75, 12-22. [CrossRef] [PubMed]

59. Hauptmann, M.; Lubin, J.H.; Stewart, P.A.; Hayes, R.B.; Blair, A. Mortality from solid cancers among workers in formaldehyde industries. Am. J. Epidemiol. 2004, 159, 1117-1130. [CrossRef] [PubMed]

60. Youk, A.O.; Marsh, G.M.; Stone, R.A.; Buchanich, J.M.; Smith, T.J. Historical cohort study of US man-made vitreous fiber production workers: III. Analysis of exposure-weighted measures of respirable fibers and formaldehyde in the nested case-control study of respiratory system cancer. J. Occup. Environ. Med. 2001, 43, 767-778. [CrossRef]

61. Aung, W.Y.; Sakamoto, H.; Sato, A.; Yi, E.E.; Thein, Z.L.; New, M.S.; Shein, N.; Linn, H.; Uchiyama, S.; Kunugita, N.; et al. Indoor Formaldehyde Concentration, Personal Formaldehyde Exposure and Clinical Symptoms during Anatomy Dissection Sessions, University of Medicine 1, Yangon. Int. J. Environ. Res. Public Health 2021, 18, 712. [CrossRef]

62. Waschke, J.; Bergmann, M.; Bräuer, L.; Brenner, E.; Buchhorn, A.; Deutsch, A.; Dokter, M.; Egu, D.T.; Ergün, S.; Fassnacht, U.; et al. Recommendations of the working group of the Anatomische Gesellschaft on reduction of formaldehyde exposure in anatomical curricula and institutes. Ann. Anat. 2019, 221, 179-185. [CrossRef] 
63. Jalali, M.; Moghadam, S.R.; Baziar, M.; Hesam, G.; Moradpour, Z.; Zakeri, H.R. Occupational exposure to formaldehyde, lifetime cancer probability, and hazard quotient in pathology lab employees in Iran: A quantitative risk assessment. Environ. Sci. Pollut. Res. Int. 2021, 28, 1878-1888. [CrossRef]

64. Bhat, D.; Chittoor, H.; Murugesh, P.; Basavanna, P.N.; Doddaiah, S. Estimation of occupational formaldehyde exposure in cadaver dissection laboratory and its implications. Anat. Cell Biol. 2019, 52, 419-425. [CrossRef]

65. Bouraoui, S.; Mougou, S.; Brahem, A.; Tabka, F.; Ben Khelifa, H.; Harrabi, I.; Mrizek, N.; Elghezal, H.; Saad, A. A combination of micronucleus assay and fluorescence in situ hybridization analysis to evaluate the genotoxicity of formaldehyde. Arch. Environ. Contam. Toxicol. 2013, 64, 337-344. [CrossRef]

66. Teng, S.; Beard, K.; Pourahmad, J.; Moridani, M.; Easson, E.; Poon, R.; O’Brien, P.J. The formaldehyde metabolic detoxified on enzyme systems and molecular cytotoxic mechanism in isolated rat hepatocytes. Chem. Biol. Interact. 2001, 130-132, 285-296. [CrossRef]

67. Saito, Y.; Nishio, K.; Yoshida, Y.; Niki, E. Cytotoxic effect of formaldehyde with free radicals via increment of cellular reactive oxygen species. Toxicology 2005, 210, 235-245. [CrossRef]

68. Jiang, S.; Yu, L.; Cheng, J.; Leng, S.; Dai, Y.; Zhang, Y.; Niu, Y.; Yan, H.; Qu, W.; Zhang, C.; et al. Genomic damages in peripheral blood lymphocytes and association with polymorphisms of three glutathione S-transferases in workers exposed to formaldehyde. Mutat. Res. 2010, 695, 9-15. [CrossRef]

69. Aydin, S.; Canpinar, H.; Ündeğer, Ü.; Güç, D.; Çolakoğlu, M.; Kars, A.; Başaran, N. Assessment of immunotoxicity and genotoxicity in workers exposed to low concentrations of formaldehyde. Arch. Toxicol. 2013, 87, 145-153. [CrossRef] [PubMed]

70. Viegas, S.; Ladeira, C.; Nunes, C.; Malta-Vacas, J.; Gomes, M.; Brito, M.; Mendonca, P.; Prista, J. Genotoxic effects in occupational exposure to formaldehyde: A study in anatomy and pathology laboratories and formaldehyde-resins production. J. Occup. Med. Toxicol. 2010, 5, 25. [CrossRef] [PubMed]

71. Costa, S.; Coelho, P.; Costa, C.; Silva, S.; Mayan, O.; Santos, L.S.; Gaspar, J.; Teixeira, J.P. Genotoxic damage in pathology anatomy laboratory workers exposed to formaldehyde. Toxicology 2008, 252, 40-48. [CrossRef]

72. Burgaz, S.; Erdem, O.; Cakmak, G.; Erdem, N.; Karakaya, A.; Karakaya, A.E. Cytogenetic analysis of buccal cells from shoeworkers and pathology and anatomy laboratory workers exposed to n-hexane, toluene, methyl ethyl ketone and formaldehyde. Biomarkers 2002, 7, 151-161. [CrossRef]

73. Duhayon, S.; Hoet, P.; Van Maele-Fabry, G.; Lison, D. Carcinogenic potential of formaldehyde in occupational settings: A critical assessment and possible impact on occupational exposure levels. Int. Arch. Occup. Environ. Health 2008, 81, 695-710. [CrossRef] [PubMed]

74. Deeks, J.J.; Higgins, J.P.T.; Altman, D.G. Chapter 10: Analysing Data and Undertaking Meta-Analyses. In Cochrane Handbook for Systematic Reviews of Interventions; Version 6.2 (updated February 2021); Higgins, J.P.T., Thomas, J., Chandler, J., Cumpston, M., Li, T., Page, M.J., Welch, V.A., Eds.; Cochrane: London, UK, 2021; Available online: www.training.cochrane.org/handbook (accessed on 15 December 2021). 